\title{
Contents, Volume 9 (1998)
}

Ahola, M.: Noctuoidea (Lepidoptera) from Cyprus collected in December-January 1993-1994, with descriptions of larvae of some species 19-36

Choi, S-W.: Taxonomy of the genus Plemyria Hübner, 1825 (Lepidoptera, Geometridae, Larentiinae) ... 185-196

Fossli, T-E. \& Andersen, J.: Host prefeence of Cisidae (Insecta: Coleoptera) on tree-inhabiting fungi in northern Norway $65-78$

Fürsch, H.: New Scymnus (Pullus)-species from Uganda (Coleoptera, Coccinellidae) ......................... 85-94

Hellqvist, S. \& Larsson, S.: Host accptance and larval development of the gall midge Dasineura tetensi on resistant and susceptible black currant. 95-102

Hirvenoja, M. \& Michailova, P.: The karyotype and morphology of Chironomus brevidentatus sp. n. (Diptera, Chironomidae). A species with a "salinarius type" larva from northern Finland $225-236$

Jalava, J. \& Miller, W. E.: Boreal Olethreutini (Lepidoptera: Tortricidae): New synonymies and holarctic records $137-142$

Jussila, R.: The genera Lissassis Townes and Singalissaspis gen. n. (Hymenoptera, Ichneumonidae) ..... 103-114

Kaila, L.: Redescriptions of Elachista heteroplaca Meyrick and Platyphyllis leucosyrma Meyrick, with descriptions of two new species (Lepidoptera, Elachistidae) ........ $53-63$

Kuznetsov, V. I., Jalava, J. \& Kullberg, J.: The leaf-rollers (Lepidoptera, Tortricidae) of Western Tuva

197-209

Laasonen, E. M., Laasonen, L. \& Nybom, O.: Trichoptera in Finnish biogeographical provinces ........ 115-135

Leinonen, R., Söderman, G., Itämies, J., Rytkönen, S. \& Rutanen, I.: Intercalibration of different light-trap designs used in moth monitoring in northern Europe ... .. 37-51

Linnavuori, R. E. \& Modarres, M.: Studies on the Heteroptera of the Khorasan province in N. E. Iran. I. Nepomorpha, Gerromorpha, Leptopodomorpha, Cimicomorpha (Nabidae, Anthocoridae), and Pentatomorpha (Coreoidea) 237-241

Lis, J. A.: Amnestus raunoi $\mathrm{n}$. sp. from Iran, the first Old World representative of the New World subfamily Amnestinae (Hemiptera: Heteroptera: Cydnidae) .... 5-7

Mamaev, B. \& Ìkland, B.: The genus Bryomyia Kieff. (Diptera, Cecidomyidae): a review of Holarctic species and Fennoscandian records 147-152

Mamaev, B. M. \& I. Zaitzev, A. I.: Sylvenomyia gen. n. in Sweden and a key to the genera of the tribe Winnertziini (Diptera: Cecidomyidae, Porricondylinae)

Nartshuk, E. P.: A revision of grassflies of the tribe Chloropini (Diptera, Chloropidae) of Finland, Estonia and
North-West Russia $153-183$ Nupponen, K. \& Junnilainen, J.: Ephestia animalella sp.n. from Southern Ural mountains .................. 143-146

Roslin, T.: Is Aphodius contaminatus (Herbst) (Coleoptera, Scarabaeidae) a threatened species in Finland? ......... 79-84

Saarinen, K., Marttila, O. \& Juntunen, J.: Karelia Biodiversity Study: Species richness and distribution of butterflies (Lepidoptera:Hesperioidea, Papilionoidea) in agricultural environment in southeastern Finland ......... 9-18

Vainikainen, V., Itämies, J., Pulliainen, E. and Tunkkari, P.: Mobility, population size and life time pattern of Carabus glabratus (Coleoptera, Carabidae) under extreme northern conditions $217-224$

Brief report

Lappalainen, H. \& Simola, H.: The fire adapted flatbug Aradus laeviusculus Reuter (Hetroptera, Aradidae) found again in Finland (North Karelia, Koli National Park) .. 3-4

Sääksjärvi, I. E.: One Cryptinae genus (Hymenoptera, Ichneumonidae) new to Finland ............................... 8

Várkonyi, G.: Notes on Leptocampoplex cremastoides (Hymenoptera, Ichneumonidae, Campopleginae), a new genus and species to the Finnish fauna ....... 215-216

Várkonyi, G.: Metopius harpyiae (Hymenoptera, Ichneumonidae, Metopiinae) new to Finland 52

Short reports (titles modified)

Haarto, A.: Aenigmatias lubbocki (Verrall) (Diptera, Phoridae) new to Finland 1

Haarto, A.: New provincial records of the Diptera Platycheirus jaerensis Nielsen (Syrphidae), Cynomya mortuorum (Linnaeus), Melinda viridicyanea (RobineauDesvoidy) and Pollenia hungarica Rognes (Calliphoridae) and Disccachaeta pumila (Meigen) (Sarcophagidae)

Haarto, A.: Faunistic rarities, Diptera Platycheirus occultus Goeldlin, Maibach \& Speight (Syrphidae) ............ 2

Lagercrantz, C-G.; Faunistic rarities, Lepidoptera Heliothis viriplaca (Hufn.) (Noctuidae)

Muona, J.: Faunistic rarities, Coleoptera Attagenus smirnovi Zhant. (Dermestidae)

Rinne, V \& Vasarainen, A . Stenocronus major (Homoptera) new to Finland

Roslin, T.: Faunistic rarities, Coleoptera Aphodius sphacela- 
tus (Panz.) and A. granarius (L.) (Scarabaeidae) .... 2 Silfverberg, H.: New provincial record of the Coleoptera Magdalis barbicornis (Latr.) (Curculionidae)

\section{Announcements}

The 25th Nordic-Baltic Congress of Entomology, Vestfold, Norway 28.06.-02.07.2000 214

Reviews

Nilsson, A. (ed.) 1997: Aquatic insects of North Europe. A taxonomic handbook. Volume 2 (Juhani Itämies) .....
INDEX to genera and species, Volume 9 (1998)

243-249

CONTENTS, Volume 9 (1998) 